Sign Systems Studies 30.1, 2002

\title{
Understanding life: Trans-semiotic analogies
}

\author{
Andres Luure \\ Department of Semiotics, University of Tartu \\ Tiigi 78, 50410 Tartu, Estonia ${ }^{1}$ \\ e-mail: luure@ut.ee
}

\begin{abstract}
This paper sketches a network of analogies reaching from linguosemiotics (including theory of reference in analytical philosophy of language) to biosemiotics. It results in the following proportion: attributive use of referring expressions : referential use of referring expressions : 'generative' use of referring expressions $=$ signifying : referring : 'poetic pointing' = 'functional' semiosis : 'adaptational' semiosis : semiosis in the narrow sense.
\end{abstract}

Can the essence of life - or, at least, our concept of life - be understood in a semiotic framework? An obvious difficulty for such an enterprise seems to be the problematic character of the extension of the semiotic concepts outside of the realm of the human. Any talk of life in semiotic terms is often regarded as merely metaphorical ${ }^{2}$ : semiosis or signs in a proper sense presuppose consciousness, that is, human agents.

This paper aims at suggesting that the plainly metaphorical character of the attribution of semiosis to life could be avoided by means of a network of analogies extending from within the human realm to life in general. First, a fragment of a theory of referring will be sketched, providing a distinction between uses of referring expres-

\footnotetext{
${ }^{1}$ Private address: Nelgi 34-20, 11211 Tallinn, Estonia.

${ }^{2}$ However, the metaphorical character of some conception need not imply its inferiority. For a discussion of the constitutive role of models, analogies and metaphors in science see Emmeche, Hoffmeyer (1991).
} 
sions. Then, an analogy will be suggested, extending the form of this distinction to a distinction of reference from some similar linguosemiotic relations. And finally, the analogy will be extended to yield a general semiotic distinction between types of semiosis involving both anthropo- and biosemiotics.

\section{Referring}

In analytical philosophy of language, referring (also called denoting ${ }^{3}$ ) is usually construed as a relation ${ }^{4}$ between a linguistic expression (the referring expression) and an existing ${ }^{5}$ object referred to (called the reference of the referring expression). Of course, referring expressions have to be provided by a certain language. ${ }^{6}$ Further, it should be noted that in the relation of the referring expression and its reference, the first member may be construed either as a type or as a token. The referring expression can be regarded to be a type when its reference is determined plainly by its linguistic form. E.g., whenever the referring expression ' $2+2$ ' is used in the language of arithmetic, its reference is 4. In general, however, the reference of a referring expression depends on the context of its use. Every token (i.e., occurrence) of a referring expression is involved in a certain act of referring along with a certain use of the expression. Think about the variety of (deictic and anaphorical) referring uses of the expression 'this' and the huge amount of the possible references of its tokens.

${ }^{3}$ These terms sometimes are experienced to have different nuances of meaning, see footnote 8 , below.

${ }^{4}$ The nature of this relation is described as "standing for" or "picking out".

5 The existence of an object is not clearly defined. One can speak of present physical existence (as of the Pope), present mental existence (as of my present thought that semiotics lacks enough system), past or future physical (or mental) existence (as of my grandparents or grandchildren), or abstract existence (as of numbers according to Platonist philosophy of mathematics, or meanings (senses) and concepts according to Frege (1892a, 1982b)). Fictional objects (like unicorns or Shakespeare's Hamlet) usually are regarded as non-existent, but one also may speak of their fictional existence. The author of this paper holds that in an adequate theory of referring, referring expressions refer to objects in some model.

6 The linguistic resources underlying a referring expression vary. Typically, referring expressions are nominal phrases ('my home'), proper names ('Italy') or pronouns ('this'). 
A class of referring expressions is constituted by what Russell (1905) introduced as "definite descriptions". 7 A definite description is meant to determine its reference by specifying a condition met by precisely one object, which is the reference. E.g., the expression 'the present President of France' refers to the unique object being at present (September 7, 2001) the President of France — a person called Jacques Chirac. Donnellan (1966) distinguishes between the "attributive use" and the "referential use" of definite descriptions. In the attributive use, the reference is strictly determined by its fitting the description, i.e., meeting the specifying condition. In the referential use, the definite description merely has to identify the reference, independently of its meeting the description or otherwise. Donnellan uses an example which goes as follows. At a party I introduce a person to my friend, saying "That man drinking martini is married to Jane" and pointing to a drinking man sitting in the corner. Now, in all probability, I succeed in referring to the right person even if he, in fact, is drinking water. So, a definite description is used to refer to its reference in a non-attributive way, the referential way. In another example by Donnellan, $\mathrm{Mr}$ Smith has been brutally murdered. "Smith's murderer must be insane, "a woman who knew him comments. Whoever murdered Smith is insane because Smith was a very kind man. Here the definite description 'Smith's murderer' is used attributively. Later on, Jones is on trial, charged with Smith's murder. His behaviour in the court is very queer, and people say: "Smith's murderer must be insane." Whoever the real murderer may be, here the expression 'Smith's murderer' refers to Jones; this definite description is used referentially.

Attributive use and referential use are not restricted to definite descriptions. They also can be distinguished in the case of proper names. Kripke (1980: footnote 3 of the main text) gives the following example. Two men are watching a remote man whom they hold to be Jones. "What is Jones doing?" "He is raking leaves." But in fact the distant man is Smith, and the name 'Jones' here refers to Smith. The name 'Jones' here is used referentially. ${ }^{8}$

${ }^{7}$ Russell himself denied that definite descriptions really were involved in the relations of referring ("denoting").

${ }^{8}$ Kripke opts for reserving the term 'referring' to the 'attributive' use of names (in this example Jones, in this use, refers to Jones, and in general, ' $x$ ''s reference is $x$ ) and wonders if he should use the term 'denoting' instead. 


\section{Andres Luure}

How general can we make the distinction between the attributive use and the referential use of referring expressions? Are there any limits in terms of the appropriate type of expressions, or again, in terms of what causes the possible apparent inadequacy of the referring expression in the case of the referential use?

The proposal of an answer to be given in this section proceeds from the assumption that the relation of referring relates a referring expression to an object in a model ${ }^{9}$ in the user of the expression or in the audience, and not to a "real" object. ${ }^{10}$ Then, for the definite descriptions the following distinctive criterion is suggested: in the case of a model switch (transition from one model (source model) to another (target model $)^{11}$ ), in the attributive use, the reference of the expression in the target model is the object fitting the description ${ }^{12}$ in the target model; in the referential use, the reference of the expression in the target model is the same as in the source model. ${ }^{13} \mathrm{~A}$ model switch can occur both as a change in actual beliefs and as a consideration of a possibility held to be counterfactual and a switch from one possibility to another.

Reconsider the example about Smith's murderer. The standard interpretation of the attributive use (in principle shared by Donnellan

${ }^{9}$ By a model, a stock of potential objects along with a system of potential beliefs about them is meant. The objects and beliefs in a model are potential in the sense that the objects need not be meant to be real and actual, and the "beliefs" need not be believed but they could be believed or "as if" (fictitiously) believed. The ways objects may be constituted in models is precisely the subject matter of the classification of the uses of referring expressions.

${ }^{10}$ An independent argument for this assumption is that such a relation lacks the "mystical" character of a relation between a referring expression and its "real" reference. Besides, this assumption renders the theory of referring less complicated and more natural, and unties it from metaphysical problems.

11 The typical instances of model switch are change in beliefs (some actual belief(s) become(s) disbelief(s) and/or vice versa) and consideration of possible worlds (construed as modifications of the actual world by counterfactual conditions as in Kripke (1980)) held to be non-actual (transition from the actual world to another possible world; both worlds are represented as models).

${ }^{12}$ Target models without a unique object fitting the description are excluded in the attributive use.

${ }^{13}$ Target models in which this object does not exist are excluded in the referential use. 
$\left.(1966)^{14}\right)$ presumes that the expression 'Smith's murderer' refers to Smith's actual murderer in the actual world and to Smith's murderer in any possible world in which someone else (a definite person) murdered Smith. According to my own interpretation, in the case of the attributive use, "Smith's murderer" refers to Smith's murderer in any model in which a definite person murdered Smith. And in the case of the referential use, "Smith's murderer" refers to a certain person who, in some model, murdered Smith. In Donnellan's example, the model switch in the case of the attributive use must be based on the woman's presumption (probably as a belief) that a definite person murdered Smith (otherwise she probably would not have said "Smith's murderer" not mentioning that Smith could not have been murdered or that there could be more than one person participating in the murder). This presumption need not specify who the murderer is, and leaves room for different models based on mutually incoherent versions. Switching between those models shifts the reference of "Smith's murderer" according to the model's version. And in the case of the referential use, the model switch is based on the belief that Smith's murderer is Jones. Should this belief be replaced with an alternative belief, a model switch would occur, not affecting the reference.

The concepts of attributive use and referential use could be generalized, rendering them independent of the linguistic form of the referring expression and reasons of model switches: independently of the linguistic form of the referring expression, it is used attributively if after a model switch its reference is meant to be the object fitting the description in the target model and it is used referentially if after a model switch its reference is meant to be the object fitting the description in the source model. The generality of this formulation is limited by the requirement that the referring expression imply a definite description, or in other words, specify a condition uniquely determining its reference.

Reconsider Kripke's example. When two men speak about Jones raking leaves they have a model in which the man they are watching is Jones. In the case of a model switch to a model in which the man watched is Smith, in the target model "Jones" does not pick out the

${ }^{14}$ Admittedly, Donnellan (1966) attributes the attributive use of definite descriptions to Russell (1905), thus involving Russell's denying of definite descriptions as referring expressions. 
man they are watching because he is not Jones. "Jones" is used referentially because after the model switch it cannot be used to refer to the person meant. Further, "Jones" implies a specifying condition because otherwise there would be no criterion for telling that the man watched is not Jones. ${ }^{15}$ Here we have another formulation of a general definition of the attributive use and the referential use of referring expressions: a referring expression implying a definite description is used attributively if it can be used to refer to the reference meant after any model switch with a target model in which there is precisely one object fitting the description, and is used referentially if there is a model switch with a target model in which this expression cannot be used to refer to the reference meant.

The attributive use and the referential use of referring expressions allow further interpretation: they correspond to different ways of identification of objects in models. The attributive use corresponds to a functional way of identification: the object meant is the object having such and such function (under the presumption of the uniqueness of such an object). We also can say that this is a conceptual way of identification because the reference is determined by its concept. Then the model simply declares an object by its definite description. The referential use corresponds to a way of identification such that the identity of the object referred to is independent of descriptions picking it out in one or another model, concepts we have of it, and functions we mean it to fulfil. What counts is the object itself: its identity is borne by itself, and not by our concept of it. So in the case of the attributive use, the reference as an object through models is tied to a concept, whereas in the case of the referential use, the reference as an object is free from any particular concept, though in any given model it can be picked out by some concept.

Can an object in a model be even more independent of and free from the referring expression? I am going to introduce such a use of referring expressions - the "generative" use. In the case of the generative use, an object in a model is introduced or "generated" or declared implying no definite description or specifying conception. Instead, the identity of the object is meant to be maintained without any identifying character or essential property, and it can be identified

${ }^{15}$ Kripke (1980), in fact, deals with in proper names used referentially, but only regard to model switches due to transition from the actual world to possible worlds, not due to changes in beliefs. 
only by a "name" ". The generative use of referring expression is quite frequent in mathematics where often objects are introduced in such a way: "let $A$ be a set consisting of $a$ and $b$ ". In a model, the elements $a$ and $b$ are created, and they are created as different though there is no other means of distinguishing them than their different names ' $a$ ' and ' $b$ '. ${ }^{17}$ We also may imagine a world containing several exactly similar physical objects with symmetrical relations to each other. Then the names identifying them are used generatively. Such names need not have the linguistic form of a constant or of a proper name: any expression, in principle, may be used creatively.

So we have built a base for analogies: the attributive use, the referential use and the generative use of referring expressions.

\section{Signifying, referring and beyond}

Let me take the next step: constructing an analogy within linguosemiotics.

I proceed from the distinction between signifying and referring. ${ }^{18}$ In signifying, the role played by models in referring, is played by languages. A signifying expression signifies an item in a language. So the signifying/referring distinction reduces to the language/model distinction. I am going to describe this distinction in analogy with the distinction between the attributive use and the referential use of referring expressions.

Leaving aside the communicative aspect, a language belongs to a signifying subject just as a model belongs to a referring subject. A model contains objects meant to be independent of and free from the

${ }^{16}$ Unlike the names in Kripke (1980), these names do not imply distinctive marks in the actual world (neither in some possible world), as a person's precise date and place of birth.

${ }^{17}$ What if we introduce a relation $R$ such that $a R b$ holds, whereas $b R a$ does not hold? The relation $R$ also is introduced generatively. What beyond its name distinguishes it from the relation $Q$ such that $b Q a$ holds, whereas $a Q b$ does not hold (for unambiguity, let $a R a, b R b, a Q a$ and $b Q b$ hold)?

${ }^{18}$ This distinction is not received. Sometimes what I call referring is referred to as signifying. My points of departure in fixing this distinction are Saussure's (1916) use when he introduces the terms 'signifier' (significant) and 'signified' (signifié), the concept of referring in analytical philosophy of language, and my proposal to take the references to belong to models (above, previous section). 


\section{Andres Luure}

linguistic form of referring to them. However, they need some referring expression in order to be identified. A language contains items meant to be tied to the linguistic forms signifying them as the sides of a sheet of paper or a coin are tied together (the relation between the signifier and the signified as described in Saussure (1916)).

How is the analogy structured? In distinguishing between the attributive use and the referential use of referring expressions, we referred to the degree of the tiedness of the objects referred to to the referring expressions. In distinguishing between the signifying relation and the referring relation, we compare the degree of the tiedness of the objects referred to their referring expressions and the degree of the items signified to their signifying expressions. So far, we have two degrees of tiedness. The first degree of tiedness is "like a sheet of paper". It applies to the way signifiers are related to their signifieds with regard to their unconcern in extralinguistic reality, and to the way referring expressions used attributively are related to their references with regard to their unconcern in the identity of the references. The second degree of tiedness could be called "one-end looseness" 19 . It applies to the way referring expressions are related to their references with regard to their concern in extralinguistic reality accessible via models ${ }^{20}$, and to the way referring expressions used referentially are related to their references with regard to their concern in the identity of their references accessible via definite descriptions.

So signifying and referring stand in the same "proportion" 21 as the attributive use and the referential use of referring expressions. To complete the analogy, it remains to find a linguosemiotic relation similar to signifying and referring and analogous to the generative use of referring expressions. The third degree of tiedness, characteristic of the generative use of referring expressions, could be called "floating looseness" 22 .

${ }^{19}$ In the referential use, the identity of an object is tied only to its definite description in one model.

${ }^{20}$ Concerning referring, extralinguistic reality is linguistically describable, that is, representable by models. Models are limited in that they are meant to consist of really or fictionally existing objects.

${ }^{21}$ If the relation between $A$ and $B$ is analogous to the relation between $C$ and $D$ then we could say that $A$ and $B$ stand in the same proportion as $C$ and $D$, or, $A: B=C: D$.

${ }^{22}$ In the case of the generative use of referring expressions, the identity of an object referred to is not earthed by any definite description in any model. 
The reference is generated along with the referring expression referring to it, that is, its name. Analogously, in the case of the third degree of tiedness between linguistic expressions and their content, using language is a creative activity with regard to reality. The linguistic expressions 'poetically point' to the reality being created, a reality not captured in models. The successive loosening of the tie could be illustrated by telling that, typically, signifying centres around words, referring centres around sentences, and poetic pointing centres around texts. Further specification of the relation of poetic pointing transcends the limits of this article. However, following the leading idea of this article, new concepts can be introduced by means of analogy, placing them into blanks in proportions. So, poetic pointing could be introduced as the missing member $x$ in the proportion:

attributive use $:$ referential use $:$ generative use $=$ signifying $:$ referring $: x$.

\section{Life}

Now we are approaching the central concern of this article: how can life be understood in a semiotic framework? Let me start from the conclusion: two types of biosemiosis are related to anthroposemiosis as the first, the second and the third members of our proportion.

How is floating looseness characteristic of the human realm? All anthroposemiotic means, including languages and models, belong to humans in a peculiar way. They depend on being maintained by humans, having no independent existence. They are untied from the humans' physical existence. I call the types of semiosis corresponding to one-sided looseness and to "like a sheet of paper", adaptational semiosis and functional semiosis. The life of the subject of adaptational semiosis (the adaptational subject) is constituted by its efforts to survive. It adapts itself to its environment by changing its properties. Its properties constitute a "natural model" (in contrast of the model proper, not reducible to properties, as described above in the context of referring). The life of the subject of functional semiosis is constituted by functional circles (Uexküll 1973, 1980, 1982, 1992). ${ }^{23}$

\footnotetext{
${ }^{23}$ For my interpretation of the functional circle see Luure (2001).
} 


\section{Andres Luure}

It has no properties it can change, and so all meanings belong to its life as its reverse side.

The functions fulfilled by semiotic, non-bodily "expressions" belong to properties in the case of the adaptational subject and to parts (a reverse side is a part) in the case of the functional subject. Functioning and adaptation are aspects of life, also belonging to humans. Therefore, in a broader sense, these biosemiotic functions also belong to anthroposemiotics, the proportion "functioning : adaptation : expression" being part of the anthroposemiotic network of analogies.

\section{Concluding comments}

After suggesting this network of analogies I would like to sketch its further connections.

The nodes of the proportions here have the metaphorical names "like a sheet of paper", "one-ended looseness" and "floating looseness". Perhaps no straightforward unambigous formulation can be given to them, and perhaps their logical foundations coincides with that of Peirce's (1998) categories of Firstness, Secondness and Thirdness. They stand in proportion with Type One, Type Two and Type Three in Luure (2001) where the number of nodes is extended to six.

\section{References}

Donnellan, Keith 1966. Reference and definite descriptions. Philosophical Review 75: 281-304.

Emmeche, Claus; Hoffmeyer, Jesper 1991. From language to nature - the semiotic metaphor in biology. Semiotica 84(1/2): 1-42.

Frege, Gottlob 1892a. Über Sinn und Bedeutung. Zeitschrift für Philosophie und philosophische Kritik 100: 25-50. [English translation: On sense and reference. In Frege (1952).]

- 1892b. Über Begriff und Gegenstand. Vierteljahresschrift für wissenschaftliche Philosophie 16: 192-205. [English translation: On concept and object. In Frege (1952).]

- 1952. Translations of the Philosophical Writings of Gottlob Frege. Geach, P.; Black, M. (eds.). Oxford: Blackwell.

Kripke, Saul A. 1980. Naming and necessity. Cambridge: Harvard University Press. 
Luure, Andres 2001. Lessons from Uexküll's antireductionism and reductionism: A pansemiotic view. Semiotica 134(1/4): 311-322.

Peirce, Charles Sanders 1998 [1903]. Sundry logical conceptions. In: Peirce Edition Project (ed.), The Essential Peirce: Selected Philosophical Writings, vol.2 (1893-1913). Bloomington: Indiana University Press, 267-288.

Russell, Bertrand 1905. On denoting. Mind 14: 479-493.

Saussure, Ferdinand de 1916. Cours de linguistique générale. Paris: Payot. English translation: Course in general linguistics. London: Duckworth, 1983.

Uexküll, Jakob von 1973 [1920, 1928]. Theoretische Biologie. Frankfurt: Suhrkamp.

- 1980. Kompositionslehre der Natur: Biologie als undogmatische Naturwissenschaft: Ausgewählte Schriften. Frankfurt: Ullstein.

- 1982. The theory of meaning. Semiotica 42(1): 25-82.

- 1992. A stroll through the worlds of animal and men. Semiotica 89(4): 273391.

\section{К понимаю жизни: транссемиотические аналогии}

В статье начертана сеть аналогий, простирающаяся от лингвосемиотики (включая теорию референции в аналитической философии языка) до биосемиотики. Получается следующая пропорция: атрибутивное употребление референтных выражений: референциальное употребление референтных выражений : “генеративное" употребление референтных выражений = означение (сигнификация) : референция :“поэтическое указывание" = "функциональный семиозис": "адаптационный семиозис": семиозис в узком смысле.

\section{Elu mõistmise poole: transsemiootilised analoogiad}

Artikkel visandab analoogiate võrgustiku, mis ulatub lingvosemiootikast (sealhulgas osutusteooriast analüütilises keelefilosoofias) biosemiootikasse. Tulemuseks on järgmine proportsioon: osutavate väljendite atributiivne kasutus : osutavate väljendite referentsiaalne kasutus : osutavate väljendite "generatiivne" kasutus = tähistamine (signifitseerimine) : osutamine : "poeetiline viitamine" = "funktsionaalne semioos" : "adaptatsiooniline semioos" : semioos kitsas mõttes. 